\title{
The topography of Anglo-Saxon London
}

\author{
TIM TATTON-BROWN
}

\begin{abstract}
Until last year Tim Tatton-Brown was Director of the Canterbury Archaeological Trust for ten years. Before that he carried out excavations in the City of London. Published work by various scholars in the last few years has made him look again at notes he made in 1973 on the overall medieval street pattern of London inside the Roman city walls. His original inspiration for doing this was reading $W$. Page's, London: its origins and early development (1923), Sir Mortimer Wheeler's great Museum Catalogues (1927 $\sigma$ 1935), as well as Wheeler's article, published in this joumal (1934) on 'The topography of Saxon London'. Mr Tatton-Brown has now 're-excavated' and revised his 1973 notes for us.
\end{abstract}

One of the few things to have remained very little changed in the City of London for nearly one thousand years was the position of most of its streets and lanes. Unfortunately this is no longer true, and in the past few decades large numbers of medieval streets have disappeared from the map for ever to be replaced by characterless dual-carriageways that now slice through the City. Not only do these new routes replace the earlier ones, but at the same time they swallow up and destroy all the surrounding side laries and many of the old alignments disappear. Equally, property boundaries which may also have survived for at least 800 years now disappear for ever in very large redevelopments, and nowhere is this whole process more clearly seen than in the vast swathe cut for the new southern dualcarriageway that has replaced Thames Street. The whole of the western part of Upper Thames Street, with its adjoining side lanes, has been physically removed, to be replaced by a tunnelled dualcarriageway further to the south. For well over half a mile the central part of Thames Street is now so wide that it has engulfed properties on its north side, while the eastern end from the Custom House to Tower Hill, with its surrounding redevelopments, has had all signs of the medieval topography removed except for All Hallows church with its unique Anglo-Saxon arch (Taylor \& Taylor, 1965 , 399-400). On the north side of the City the new London Wall dual-carriageway has sliced through the Cripplegate fort, removing Silver Street and Addle Street, two streets which, with Wood Street, may have been in almost continuous use since the building of the Hadrianic fort in the area in the early second century AD (Grimes, I 968 ; Dyson \& Schofield, 1984). All this destruction was triggered off by the bombing of London during the last war, though in recent years many more areas that were not bombed have been redeveloped. Before this, almost all of London's medieval street plan remained intact, even though some huge new streets had been cut across the City in the later eighteenth and nineteenth centuries after the destruction of its gates and the building of Southwark Bridge and the new London Bridge (King Street, Arthur Street and Monument Street with London Bridge). Later in the nineteenth century Queen Victoria Street and an enlarged Cannon Street were cut across the earlier street pattern to join up London Bridge (and the main roads from the north and east) to the newly-built Victoria Embankment. The Kingsway, Aldwych and Waterloo Bridge developments followed in the early years of this century.

If we look at the pattern of streets in the City of London before the eighteenth century (Ogilby's magnificent map of 1676 in conjunction with the first edition of the Ordnance Survey I : I $25^{\circ}$ are the best maps to use), it is clear that we are looking at a medieval street pattern that goes back unchanged to the twelfth century at the very least and most of it probably to some time before the Norman conquest (FIG. I.) Is it possible, therefore, to work out how this street pattern evolved, particularly as it has no apparent connexion (except at the gates and in a few odd places) with the Roman pattern of streets? It 


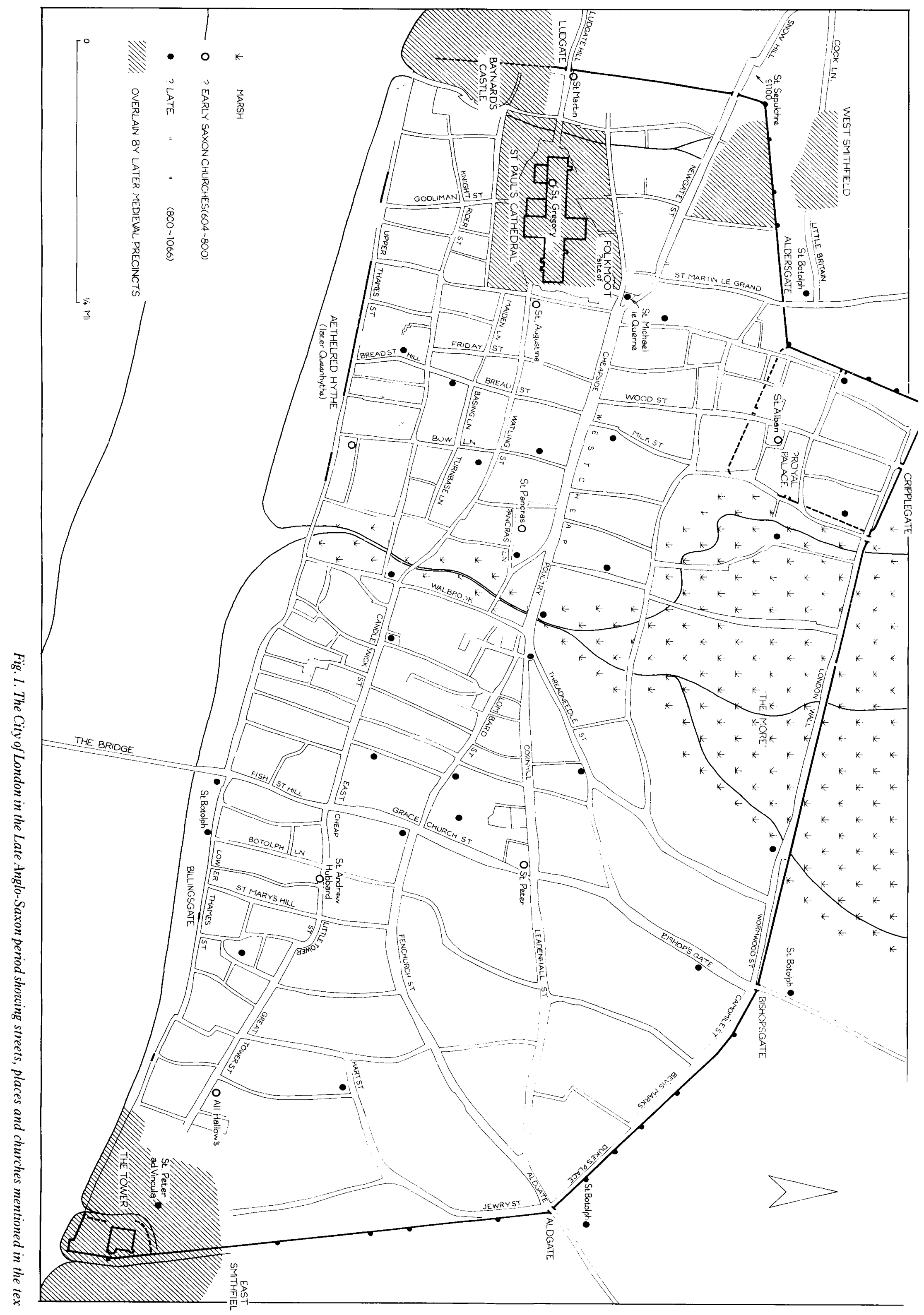




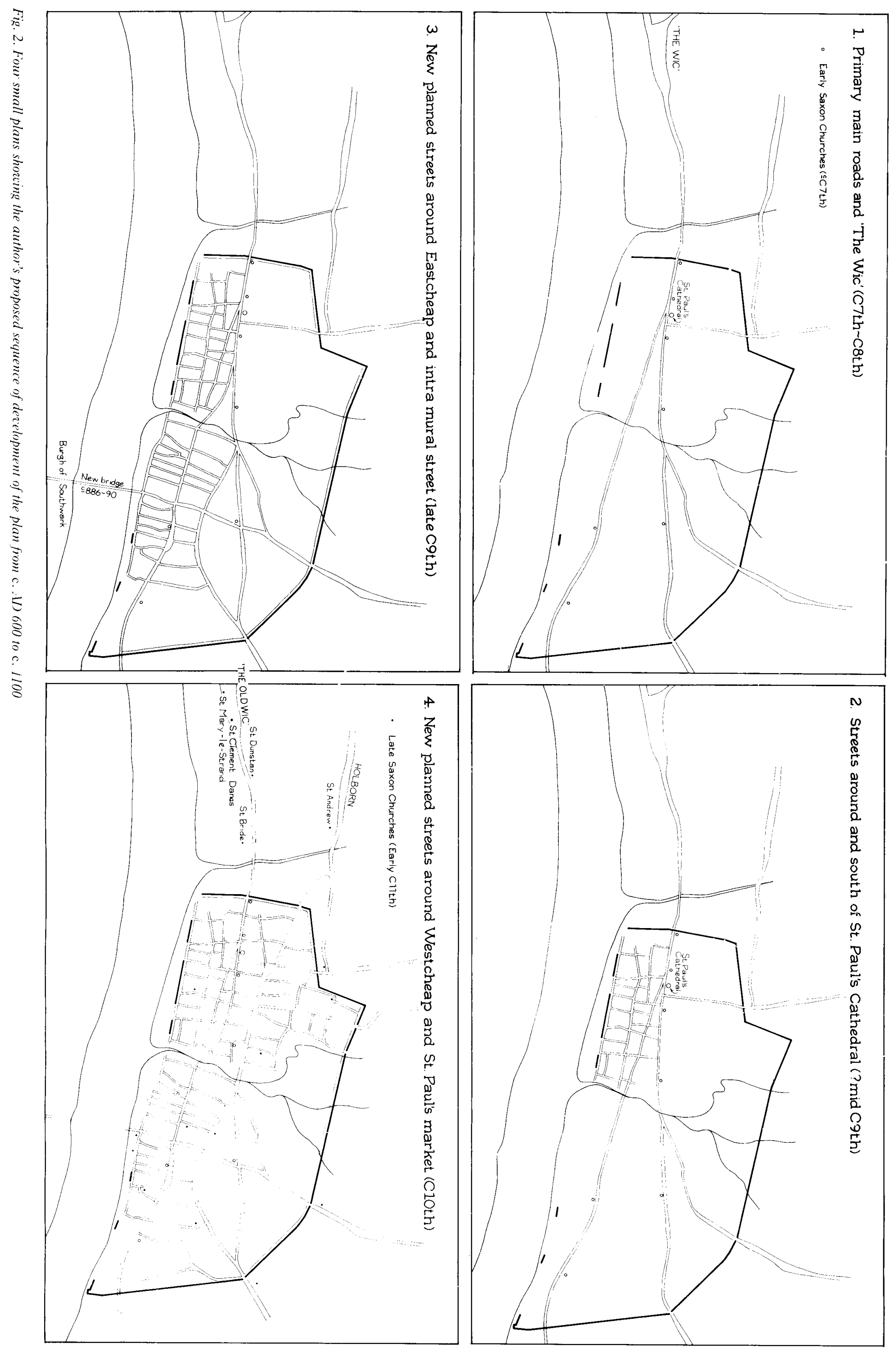


should perhaps be said here that too many recent plans, for example Dyson \& Schofield, 1984,288 Fig. 97, still try to show a connexion between the Roman and later streets, but except for the Cripplegate fort area, this just does not work.

The huge jumble of streets in and around the walled medieval City as depicted on early maps (from the late sixteenth century onwards) appears at first sight to have no logical pattern, but in many medieval cities in Britain and Europe, archaeological and topographical work in the last few decades has unravelled the way that these cities and their street patterns developed in the later Anglo-Saxon and medieval periods. Notable examples in Britain are Hereford (Shoesmith, I982) and Winchester (Biddle, 1975, 334 and Fig. 21), but many other larger and smaller towns could also be cited (Aston $\&$ Bond, 1976 have various examples), together with many examples in Europe (Barley, 1977). A start has even been made at Rome (Krantheimer, 1980), perhaps the greatest and most important medieval city of all. So what about London?

\section{THE DARK AGE}

First, it now seems very clear indeed that there is no continuity whatsoever between the Roman and medieval cities and that although sub-Roman occupation may have continued well into the fifth century, the City of London was probably a virtually empty shell, full of the decaying ruins of Roman buildings, throughout the sixth century. There may have been odd squatters among the vegetation and tumbling walls of the City, but in no sense was London a 'central place' (to use the jargon phrase) or market town at this time. The early Anglo-Saxons were after all a non-urban people. It is also almost certain that Roman London Bridge went out of use during the fifth century although the ruins of the starlings (piers) were probably still visible with perhaps a weir (in both directions) at high and low tides. We should also bear in mind that sea-level was probably rising continuously from the late Roman period onwards so that the Roman quays were being buried as well as inundated, and the gradual process of the erosion of the City walls on the south would have been under way making the foreshore here a difficult and dangerous place to land (Hill, Millett \& Blagg, I980). The sixth century for London is therefore totally 'dark', and it is not until AD 604 that Mellitus was sent from Canterbury to preach in Essex, to found a new see, based in London, and to build a new church-St
Paul's in the western part of the walled City. Bede (H.E. II, 3) actually tells us that 'king Aethelbert built a church dedicated to the holy Apostle Paul in the city of London, which he appointed as the episcopal see of Mellitus and his successors'. What did Mellitus find there and why did he build St Paul's on that particular site?

\section{THE EARLIEST STREETS}

The earliest elements in London's street plan are clearly the great through routes which cross the City from east to west and are joined by the roads from the north, entering the City through Aldersgate and Bishopsgate. These through routes are not completely clear at first glance and in places need disentangling from the later streets (FIG $2: I$ ).

The first and most important route starts as the Strand and then becomes Fleet Street and Ludgate Hill. 'This route, called 'Akemannestraete' in the late Anglo-Saxon period, enters the City at Ludgate, which was presumably a Roman gate, and is one of the 'Westgates' (the other was probably Aldersgate) mentioned in a charter of $\mathrm{AD} 857$ (Sawyer, I968, no. 208). Once inside the City this route leads directly to St Paul's where the later medieval precinct has in part obscured the original route. To the east of St Paul's, however, two streets emerge from the precinct, a southern one (later Maiden Lane, Basing Lane and Turnbase Lane), which although interrupted by the Walbrook, clearly led originally to Candlewick Street (now Cannon Street), Eastcheap and Great Tower Street, on the north side of which are the still existing remains of the late seventh- or eighthcentury church of All Hallows, Barkingside (Taylor \& Taylor, I965, 399-400). After this, the southern route is again cut off by the later Tower of London, but it seems highly likely that it originally left the City by a (possibly Roman) gate in the area north of the White Tower and continued across East Smithfield (an early extra-mural market area) to become the Radcliff Highway, an important route shown on all the earliest maps, for example Morden and Lea's 'Actual Survey' of $c .169 \circ$ (Darlington \& Howgego, 1964, Pl. 8), and leading to Shadwell, Limehouse and Poplar. There was almost certainly a Roman street on this alignment which would have led to the Roman signal station at Shadwell (Johnson, 1975).

The second and more important street to leave the St Paul's precinct area is Watling Street, possibly a significant name (see Ekwall, I954 for the meaning of the street names). Beyond the 
north/south Bread Street, this street appears to have been diverted down to join Candlewick Street (perhaps in the later ninth century when Eastcheap market was created-see below). Its original course was almost certainly due east to the important early crossing point of the Walbrook immediately to the north of the Mansion House (i.e. at the east end of Cheapside/Poultry). A vestige of this route is almost certainly Pancras Lane, and it is perhaps no coincidence that St Pancras church (with an early dedication) is just to the north of the lane here. Further west on this same route lies the now well-known, although still little discussed, row of churches with early dedications: St Martin, St Gregory, St Paul and possibly St Augustine (the later church, as in Canterbury, may be a rededication of an earlier church). The dedications of this row of churches can be very closely paralleled by the excavated row of seventh-century churches on the north side of the Roman street leading east out of Canterbury (SS Peter and Paul, St Mary, St Pancras and St Martin (Taylor \& Taylor, I965, I 34-45), and possibly the parish church of St Paul just to the west). These London churches perhaps date originally to within the century or so following the founding of St Paul's in AD 604.

Immediately this route had crossed the Walbrook, it bifurcated, one route leading to Bishopsgate (Threadneedle Street and Bishopsgate) and the other to Aldgate (Lombard Street and Fenchurch Street). A third and more curving route ran to the south (Lombard Street and Fenchurch Street). It was perhaps created in the ninth century with the founding of Eastcheap (see below), but it may be the original route which was replaced by the more direct route along Cornhill and Leadenhall Street. Another alternative possibility is that Fenchurch Street originally led to the crossing point of the Walbrook at the west end of Candlewick Street.

The third early route to St Paul's is the road that comes into the City through Aldersgate and then becomes St Martin-le-Grand. The southern end of this route is the site of an early cross and the postulated position of the early folk-moot, but it is very likely that it continued south to join the main east/west route just to the east of St Paul's, until cut off by the later medieval precinct. The meeting point of these two routes and the probable site of the original St Paul's is presumably under the crossing and choir of the present Wren cathedral. The archaeological deposits here were almost certainly totally destroyed by the early Norman crypt
(Bishop Maurice's crypt of $c .1087$ ) and by the Wren crypt. But, just to the south and west, where a few fragments of the great medieval chapter house are still visible in a small garden, the archaeology of these early levels is almost certainly still at least partly intact. One day a research excavation in this area may throw more light on the whole question of the siting of the original church. But, just as at Canterbury (Tatton-Brown, I980), it is clearly the cathedral that is the prime focus of the early medieval town, and it is therefore no coincidence that all the early routes meet at St Paul's and this, if not too circular an argument, implies that at least some of these routes may originate as routes to $\mathrm{St}$ Paul's from all over Mellitus's new diocese in Middlesex and Essex.

Another early major route to the City, and with the Bishopsgate (Ermine Street) and Aldgate (Colchester and Ipswich) routes one of the three most important long-distance Roman and later roads to the City, is that which west of the Fleet river is first called Holborn (and High Holborn, beyond the later medieval Bar) and beyond this becomes the main road to the west and connects with Watling Street. It has always been assumed that this route entered the City up Snow Hill (later replaced by Holborn Viaduct) and through Newgate, and although this was almost certainly the case in the Roman period (and under the later medieval Newgate, a large Roman gate was found), it was certainly not the case in the earlier medieval period. First, the topography of the area (clearly shown on all early maps) indicates that the road called Holborn, after crossing the Fleet at Fleet Bridge continued as Cock Lane (named after the Holborn Conduit) and ran along the south side of West Smithfield (another great early market for cattle), before becoming Little Britain and joining Aldersgate beside St Botolph's church just outside the medieval gate. It is perhaps worth noting that there are also churches dedicated to St Botolph just outside Bishopsgate and Aldgate (as well as near London Bridge), but not outside Newgate or Ludgate (the Botolph dedications are presumably eleventh-century in date). Second, Snow Hill, as it runs to Newgate, is clearly topographically secondary to Holborn and Cock Lane. It is also leading to a new gate, though only John Clark in recent times has hinted at the late date of Newgate (Clark, I978, 195-6). In my opinion Newgate and Newgate Street (as far as St Martin-le-Grand) are both later elements in the street plan which perhaps date only 
from the post-Conquest (late eleventh/early twelfth century) period. Stow, though a doubtful source, says that Newgate was erected 'about the reign of Henry I or of King Stephen' (Stow, I603: having changed it from 'about the raigne of Henry II or Richard I' in the first edition of $I_{598}$ ). It is also likely that the church of the Holy Sepulchre just outside Newgate dates from the very early twelfth century (Brooke \& Keir, 1975, 144) as at Cambridge and Canterbury, for these new round churches date from just after the capture of Jerusalem and of the church of the Holy Sepulchre in the First Crusade of I099. A post-Conquest date of $c$. I roo therefore seems likely for the street as well, although it is not impossible that the street and gate go back to the late Anglo-Saxon period. At Canterbury too, Dr Nicholas Brooks $(1984,25)$ has argued cogently for a late Saxon or early Norman date for the new High Street and Newingate (later St George's Gate, and the only definite non-Roman gate in the City walls).

These, therefore, are the early routes through the City of London. They suggest that the City in the seventh century was little more than an area where a line of early churches existed with St Paul's at the centre. There is, however, some very slender evidence for Middle Anglo-Saxon sunken huts in the area east of St Paul's although these may all be later in date (ninth/tenth century-Dyson \& Schofield, I $984,300-1$ ). If there are grubenhauser of the seventh century in the area they could be paralleled by the many sunken huts that appeared inside the walls of Canterbury (and also not far from the cathedral there) at this time. These hut sites, which produce very little in the way of datable exotic finds or coins, are very different from the 'wic' sites which appear to grow up outside the old towns in the seventh century. Martin Biddle's (1984) and Alan Vince's ( $1984 \mathrm{a} \& 1984 \mathrm{~b}$ ) very convincing new suggestion of a Lundenwic outside the Roman City walls on the west (and centring on the shore south of the Strand) can in fact be paralleled at many other places in Britain as well as on the eastern shore of the North Sea/English Channel though their significance has not yet been fully appreciated except perhaps by Dr Susan Reynolds (1977, 24-7).

\section{THE TRADING WIC}

In Britain the following probable -wic sites are known (starting in the south-west and working eastwards and northwards around the coast): Ham- wic (Southampton), Dover (Wyke below the Western heights), Sandwich, Fordwich (outside Canterbury), Lundenwic, Ipswich, Dunwich, Norwich, Lincoln (Wigford, below the Roman walled city), and York (Eoforwic), as well possibly as Harwich and Swanage (Swanawic, Reynolds, 1977 , 25) and, just possibly, Greenwich and Woolwich and Berwick(-upon-Tweed). There may well be other sites, but it is surely significant that all the sites mentioned are on the coast of south-eastern and eastern England, i.e. in the areas of early Anglo-Saxon settlement, and opposite such Continental sites as Quentovic (near Boulogne), Wijkbij-Duurstede (at the Rhine mouth and perhaps another very significant name-a wic beside a Roman fort), Schleswig, Brunswick and Bardowick. The actual siting of these 'wic' sites is in every case on a protected sea shore (or a major river connecting with the sea) and often outside, but close to, an old Roman walled site. So Hamwic is near Clausentum (and not all that far from Winchester), Sandwich is near Richborough, Fordwich is very near Canterbury (an eastern part of the extra-mural borough of Canterbury, next to Fordwich, is still called wic in Domesday Monachorum, although by this date Fordwich itself was in a liberty on its own, surrounded by the County borough on two sides (see Tatton-Brown, I984, I I and Fig. 3). Ipswich (and Harwich) are not far from Colchester (and Walton Castle/Felixstowe) and Norwich is close to Caister. Even closer parallels to London and Canterbury, however, are to be found at the two great northern cities of Lincoln and York. Lincoln has the great suburb of Wigford beside and south of the river (Wigford presumably means exactly the same thing as Fordwich, i.e. the-wic by the ford) while York takes its name from Eoforwic (later Jorvic), which must have been an Anglian trading centre on the river just outside the Roman fortress walls (Palliser, I984). The significance of all these sites is that they had a good protected foreshore on which boats and ships could be pulled up, and above which trading with the indigenous population (and each other) could take place. Temporary sites (perhaps of the sixth century) would soon become semi-permanent and, until the arrival of the Vikings in the ninth century, they were the only major trading or proto-urban centres in north-west Europe.

In London this trading centre has now been shown without doubt to be above the foreshore between St Martin's-in-the-Fields and the Fleet 
(Biddle, 1984; Vince, 1984a \& 1984b). The road along this foreshore (long known as the Strand) runs from Westminster to Ludgate. It is joined in its centre by the curving Drury Lane, and between the two a very large triangular market place grew up. In the late Anglo-Saxon period this market acquired, in its centre, two churches, St Mary-leStrand (earlier Holy Innocents, Brooke \& Keir, I 975, I 40) and St Clement Danes, the latter almost certainly a Cnut foundation of the early eleventh century (Cinthio, I968); after this, much of the centre was filled in with middle rows. The area was finally destroyed at the turn of the present century when the new D-shaped Aldwych and Kingsway were laid out.

To summarize, the London of the seventh, eighth and early ninth centuries was primarily a great trading port based around the Strand foreshore vicus and controlled by the King's reeve (the wic-gerefa); the king being initially the Kentish king (perhaps Aethelberht himself 'founded' the wic just as he had built St Paul's) followed by the kings of Essex, Mercia and Wessex. This was the 'emporium of many people coming by land and sea' of the Venerable Bede (H.E. II, 3). To the east and within the south-western part of the Roman walled area was the cathedral church of St Paul's, its eastern and western 'satellite' churches. In this area too there may have been a royal palace (perhaps near St Alban, Wood Street) and a folk-moot, though this is still hypothetical (Dyson \& Schofield, I $984,298,306-8$ ).

\section{THE NINTH CENTURY}

By the middle years of the ninth century, however, things were beginning to change in a large way, with-most important of all-the open wic sites becoming very insecure with the incursions first of the Viking raiders, and even more so with the advent of the Great Army. London was first attacked in 842 , was stormed in 851 and the 'Great Army' wintered there in $87 \mathrm{I}-2$ (all recorded in the Anglo-Saxon Chronicle). The 'age of the wics' had come to an end, and there is no doubt that the citizens of London and other great trading centres would have looked for more protected sites. In London the obvious answer was to retreat inside the Roman walls, and the mid ninth century is perhaps the time when the area around (and particularly south and east of) St Paul's was reoccupied on a large scale. It is perhaps at this time that streets running down to the river like Godliman Street and
Bread Street were first constructed and I would also go on to suggest that the fairly regular grid of streets in this part of the City perhaps belongs soon after this (i.e. in the third quarter of the ninth century) when magnates such as the Bishop of Worcester were acquiring hagas and 'burhs' in this part of London (for example, Ceolmunding Haga in 857 , Sawyer, I968, no. 208 and Whitelock, I979, 529). They all needed a more secure place, and the gridding of this area would have allowed many people to be accommodated (FIG. 2:2). The Roman city wall to the south of this area was probably still partially intact, and it would not have been difficult to refortify this area of London. This was, however, to no avail and the Vikings were able to occupy the City in autumn $87 \mathrm{r}$. It is not until after Alfred's recapture of London in 886 that a large programme of refortification took place and for nearly a century after that the City was held despite several renewed attacks.

\section{KING ALFRED'S CITY}

In their important paper on 'Late Saxon planned towns', Biddle and Hill (1971, 83) show that after London was recovered by Alfred in 886 , he 'refurbished the walls, repopulated the City and, during a conference to discuss its restoration (instauracio), assigned to various magnates plots of land bounded by streets'. Martin Biddle has also suggested that it was Alfred who restored London Bridge, although it is not mentioned until the tenth century, and built the fortified bridgehead to the south of it, i.e. Southwark (Biddle \& Hudson, r 973 , 293-5 and 308-9). This seems very probable, and I would go further and suggest that it was Alfred who repopulated the whole of the southern part of the eastern city by laying out a new 'planned town' in the area. The principal streets of this new area are a new street from the Bridge to Bishopsgate (Fish Street Hill and Gracechurch Street) and, at right angles to it and the most important street of all, a new widened Eastcheap (with Candlewick Street and Great Tower Street as continuations to the west and east). This new street market (cheap) used an earlier route across the City (see above), but considerable widening of the street must have taken place. Most important, the whole series of long narrow lanes to the north and south, which still survive to a considerable extent, were built (FIG. $2: 3$ ). These lanes, which are very similar to the lanes in the late ninth-century planned town of Winchester (Biddle, 1983 ), were an integral part of 
the new market development. On the south they ran straight down to the waterfront, and one of them (Botolph Lane) has been shown by a brief excavation perhaps to have an origin in the late ninth century (Dyson \& Schofield, I 984, 293-5 and 308-9). On the north side of Eastcheap the lanes run up to Lombard Street and Fenchurch Street, which may be an earlier street (see above), but could equally be the planned northern limit to this new market area. The lanes north of this are presumably later (tenth/eleventh century). The widest part of Eastcheap itself (Little Tower Street) is at its east end, where there is an awkward kink, perhaps a filled-in middle row, with the church of St Andrew Hubbard to the west end. In the late Saxon period this must have been an extremely busy market with direct communications down Botolph Lane, St Mary-at-Hill, etc., to Billingsgate. It is also very likely that the development of this area quickly extended eastwards so that by the Norman Conquest the whole of the area to the Roman city walls was fully occupied. Supporting evidence for this may be seen on the one hand in the peripheral nature of the (possibly mid eleventhcentury) church of St Olave (Hart Street), and on the other in the probable destruction of buildings for the construction of the Tower in the extreme south-eastern corner of the City near St Peter's church.

Apart from repopulating the City, Alfred is known to have refurbished its defences, and it is likely to have been he who not only rebuilt the Roman city walls, but also built the very long intramural street (Biddle \& Hudson, 1973, 23 and fn.), a large part of which still survives as London Wall, Wormwood Street, Camomile Street, Bevis Marks, Duke's Place and Jewry Street. Evidence for the now destroyed intramural street on the west has also come from excavation. Alfred must have also used London Bridge as a defensive structure, as well as refortifying the riverfront of the City while still allowing ships to dock there. In the western part of the City, Alfred apparently continued the policy of handing out plots of land bounded by streets to various magnates, as the now well-known charters of 889 and $898-9$ clearly illustrate (Sawyer, I968, nos. $346 \&$ I 628; Dyson, 1978). They also show how ships were moored on what must be a partially restored waterfront in the Queenhythe areas just to the south of the Roman city wall. The rise in sea level and evidence from the Mermaid Theatre/Baynard's Castle excavations in- dicate that the old city wall itself may have been used as the quay (see Fig. 13-drawn by the present writer-in Hobley \& Schofield, I977, 47-9).

\section{THE LATE ANGLO-SAXON CITY}

Following Alfred's restorations, it is clear that in the tenth century the walled City of London was rapidly filling up, and it seems most likely that the second great street market in the City, the West Cheap (later Cheapside) was created at this time FIG. $2: 4$. It is possible that it too was a creation of Alfred's time, but I think this unlikely and that it is much more probable that it was created in the time of Aethelred of Mercia (died 9II), Edward the Elder (died 924), or his son, Athelstan, who had by 927 conquered all the Scandinavian kingdoms and was styling himself 'King of All Britain'. This second great market is further away from the river, although Bread Street and Bow Lane connect it directly with the quays at Aethelred's Hythe (later Queenhythe, see above). It seems likely that this new market was more closely connected with St Paul's Cathedral and with the land, than with the sea. Sadly, the history of the Bishop and Chapter of St Paul's before the Norman Conquest is very poorly documented, but it seems a reasonable hypothesis that West Cheap was originally founded by St Paul's, just as other great religious houses in England were able at this time to found street markets. A hint for this comes from the medieval period (Brooke \& Keir, 1975, I76-7), when St Paul's was selling large amounts of produce from their manors in Middlesex and Essex, and it is no coincidence that West Cheap starts at the Cornmarket (with the ancient cross and St Michael 'le Querne' in the middle) which is just outside the north-east corner of St Paul's churchyard and close to the Canon's Brewhouse and Bakehouse (Brooke \& Keir, $1975,176-7)$. This is also the place where the ancient street coming in through Aldersgate later terminated, presumably at a gate (see above), and where the folk-moot may have been situated. As we have also seen, the markets were perhaps extended westwards from here as Newgate Street (and the Shambles) in $c$. II00 and later as Paternoster Row. Earlier, the market extended eastwards only to the Walbrook crossing, with a Fish Market, Bread Market, Milk Market, etc., all making this by far the busiest market in eleventhand twelfth-century London. When West Cheap was created, it too had a series of north and south lanes running off it (the names of the lanes very 
often relate to the markets at the end of them, e.g., Milk Street), and when this planned area was created the old through route from Watling Street to Cornhill must have been diverted down towards Eastcheap, though leaving a fragment of the old route in Pancras Lane. North of West Cheap, the street pattern extends up to the Aldermanbury area where more early hagas and burhs, as well as the possible early royal palace, are to be found (Dyson \& Schofield, 1984, 294 and 306-8). Wood Street was, from this period at least, an important route which led out through the city walls at Cripplegate (first documented $c$. I000). However, despite late Anglo-Saxon filling up of the walled area, the eastern and western parts of the City were still very separate with probably only two roads (Poultry at the end of West Cheap and Watling Street) connecting them across the Walbrook valley. The central northern area of the City both inside and outside the walls was certainly still mostly marsh (it is still called a 'Moor' at a much later date).

The final Anglo-Saxon phase in London's history is really both a Danish and an Anglo-Saxon phase. In 982 the Anglo-Saxon Chronicle tells us that the City was burnt by the Danes and in 994 and from roog to IOI $_{3}$ it was attacked again and again until it finally opened its gates to Sweyn Forkbeard in IOI3. A further period of turmoil followed from roI 4-16, which is very dramatically recorded in the Norse sagas (Wheeler, I927; Brooke \& Keir, 1975, 2I-6), and after that there was at last a period of peace which continued up to the Norman Conquest in 1066 . During this period of calm, the City must once again have been expanding not only into every available (non-marshy) corner of the walled area, but also once again back to the great extra-mural area on the west. Not only was Edward the Confessor building his great royal abbey at Westminster, but the large old market area on the Strand and in Fleet Street (perhaps first called 'Old
Wic'-Aldwych--at this time) was being revived on a very large scale. The huge area of middle rows around the churches of St Mary-le-Strand (earlier Holy Innocents demolished in I 549 and rebuilt on a slightly different site in $1714^{-7}$ ), and St Clement Danes which are depicted on the late sixteenth and seventeenth century maps (e.g., Hogenberg, I 572, Norden, 1593 and Ogilby \& Morgan, I676- see Darlington \& Howgego, 1964, nos. 2, 5 and 28) show that this area was once a very large triangular market with Drury Lane running off from the North-west corner. The dedications of the churches here, St Clement, and further east, St Dunstan and St Bride (see Brook \& Keir, I975, 14I-2; Cinthio, 1968), all suggest the first half of the eleventh century for the reinvigorating of this area, although the triangular market area around $\mathrm{St}$ Clement Danes may well be the heart of the seventh century wic which continued to be used from that time onwards whenever peace prevailed in the City. A lesser extra-mural street market to the north-west of the timber church of St Andrew in Holborn (described as 'old' in AD 959) was also probably developing at this time, and again the cigar-shape of High Holborn and Holborn (with a middle row) to the west of the Fleet Bridge also suggest this.

We have therefore in a sense come full circle in returning to the Aldwych and to the extra-mural area to the west of the City. It is this area which in the course of the next few centuries becomes the capital of England (and later Great Britain) with the shift of focus to Westminster and its royal palace.

Acknowledgements: I am very grateful to Professors Christopher Brooke, Martin Biddle, and Nicholas Brooks, and to Tony Dyson, John Schofield and David Hinton for kindly reading and commenting on an earlier draft of this article. Their notes have been extremely useful and have helped me to correct many small errors. They are not, of course, responsible for any of the speculative passages in the text.

B IB L IOG RA PHY

ASTON, M. \& J. BOND. 1976. The landscape of towns (London).

BARLEY, M. W. (ed.). I977. European towns, their archaeology and early history (London).

BEDE. Historia Ecclesiastica (H.E.).

BIDDLE, M. \& D. HILL. I97I. Late Saxon planned towns, Antiq. $\mathcal{F}$. LI, $70-85$.

BIDDLE, M. \& D. HUDSON. I973. The future of London's past (Worcester).

BIDDLe, M. I975. Excavations at Winchester, I97 I Tenth and final interim report, Antiq. $7 ., \mathrm{Lv}, 96-337$.
-, I 983 . 'The study of Winchester: archaeology and history in a British town, $1961-1983$, Proc. Brit. Acad., LxIX 37-79.

-, I984. London on the Strand, Popular Archaeology, 6. $1,23-7$.

BROOKE, C. N. L. \& G. KEIR. 1975. London 800-1216: the shaping of a City (London).

BRoOKs, N. P. Ig84. The early history of the Church of Canterbury (Leicester).

cinthio, $x$. I968. The churches of St Clement in Scandinavia, Archaeologia Ludensia, 3, ro3-16. 
Clark, J. r $97^{8}$, Cadwallo, King of the Britons, the bronze horsemen of London, in (eds) J. Bird, H. Chapman \& J. Clark, Collectanea Londiniensia, I94-9.

-, 1980. Saxon and Noman London (London).

Dartington, 1. \& J. Howgego. I964. Printed maps of London circa 1553-1850 (London).

Dyson, A. 1978. Two Saxon land grants for Queenhithe, in (eds) J. Bird, H. Chapman, \& J. Clark, Collectanea Londiniensia, 200-16.

-, I980. London and Southwark in the seventh century and later: a neglected reference, Trans. London Middlesex Archaeol. Soc., 31, 83-95.

DYSON, A. \& J. SCHOFIELD. I984. Saxon London, in (ed.) J. Haslam, Anglo-Saxon towns in Southern England (Chichester), 285-3 13 .

EKWALL, E. 1954. Street names of the City of London (Oxford).

Grimes, W. F. 1968. The Archaeology of Roman and Medieval London (London).

HOBLEY, B. \& J. SCHOFIELD. 1977. Excavations in the City of London: first interim report, I974-5, Antiq. $\mathcal{F}$, LVII, 3 I-66.

JoHnson, A. 1975. A Roman signal tower at Shadwell, E.I., Trans. London Middlesex Archaeol. Soc., 26, $278-80$.

PAGE, w. 1923. London its origin and early development (London).

PAlliser, D. M. I 984 . York's west bank: medieval suburb or urban nucleus? in (eds) P. V. Addyman \& V. E. Black, Archaeological papers from York presented to M. W. Barley, ro -8 .

REYNOLDS, S. 1977. An Introduction to the history of English medieval towns (Oxford).

SAWYER, P. H. 1968. Anglo-Saxon Charters: an annotated list and bibliography (London).

\section{Book Chronicle continued from p. 20}

The perfume industry of Mycenean Pylos by Cynthia Wright Shelmerdine. Studies in Mediterranean Archaeology, Pocket Book 34. Göteborg: Paul Astroms Förlag, 1985. 184 pp., 42 figs.

Prehistory of the eastern arctic by Moreau S. Maxwell. New World Archaeological Record series. Orlando: Academic Press, 1985. 328 pp., 149 figs., 12 tables.

Pottery kilns at Chilvers Coton, Nuneaton by Philip Mayes \& Keith Scott, edited by Shirley A. Johnson. Monograph series No. 10. London: Society for Mediaeval Archaeology, 1984. 198 pp., 8 pls., 126 figs., 10 tables.

Archaeological field survey in Britain and abroad edited by Sarah Macready \& F. H. Thompson. Occasional Paper (New Series) VI. London: Society of Antiquaries, distributed by Thames and Hudson, 1985. 252 pp., 80 figs. £15.00.

Troie I. materiaux pour l'étude des sociétés du Nord-Est Égéen au debut du bronze ancien by Michel Séfériadès. Cahier No. 15. Paris: Lditions recherche sur les Civilisations, 1985.290 pp., 24 pls., 57 figs.
SCHOFIELD, I. I984. The building of London from the Conquest to the Great Fire (London).

SHOESMITH, R. 1982 . Hereford City Excavations, volume 2: Excavations on and close to the defences (London).

STENTON, F. M. I934. Norman London, an essay (London).

stow, J. I603. A Survey of London (London, reprinted I9I2).

TATTON-BROWN, T. W. T. 1974. Excavations at the Custom House site, City of London, 1973, Transactions of London and Middlesex Archaeological Society, 25, II $7^{-2}$ ×9.

-, I975. Excavations at the Custom House site, City of London, 1973 - part 2, Transactions London Middlesex Archaeol. Soc., 26, 103-7o.

-, I980. Canterbury's urban topography: some recent work, in (ed.) P. Riden, The medieval town in Britain (Cardiff), $85-98$.

-, 1984. The towns of Kent, in (ed.) J. Haslam, Anglo-Saxon towns in Southern England (Chichester), $1-36$.

rAYLOR, H. M. \& J. 1965. Anglo-Saxon architecture (Cambridge).

VINCE, A. I984a. The Aldwych: mid-Saxon London discovered?, Current Archaeology, 93, $310-3$.

-, $1984 \mathrm{~b}$. New Light on Saxon pottery from the London area, The London Archaeologist, 4. I6, 43 I-9.

WHEELER, R. E. M. 1927. London and the Vikings (London).

-, 1934. The topography of Saxon London, Antiquity, $8,290-302$ with further thoughts by J. N. L. Myres, $437-47$.

-, 1935. London and the Saxons (London).

WHITELOCK, D. (ED.) Ig79. English Historical Documents, volume I: c. 500-1042 (Oxford, and edition).

'So much that is new'. Baldwin Spencer 1860-1929. A biography by D. J. Mulvaney \& J. J. Calaby. Carlton, Victoria: University of Melbourne Press, 1985 (distributed by HB Sales, Enterprise House, Ashford Road, Ashford, TW15 1BX). 492 pp., 68 pls. (4 colour). $£ 27.50$.

Acquarossa Vol. V. The head antefixes and relief plaques. Part 1: a reconstruction of a terracotta decoration and its architectural setting by Margareta Strandberg Olofsson. Göteborg: Swedish Institute at Rome, 1984. 158 pp., 4 pls., 49 figs.

Social adaptation to food stress: a prehistoric Southwestern example by Paul E. Minnis. Prehistory, Archaeology and Ecology series. Chicago and London: University of London Press, 1985.240 pp., 33 figs., 25 tables. £18.50.

Radioanalytical techniques in archaeology. Pottery and raw clay analysis by Andreas G. Orphanides. Nicosia: AGO Publications, 1985. 93 pp., 10 figs. C£5.00. 